\title{
LIST OF PREMIOMS
}

OF THE

\section{Rhode Island Society} FOR THE ENCOURAGFMENT OF

\section{DOMESTIC INDUSTRY}

WITH THE

Pules, Regulations and Programms roge mits

\section{CATTLE SHOW AND EXHIBITION} AT

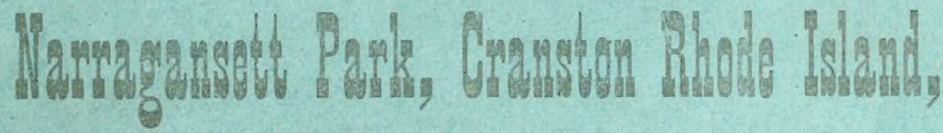

$$
\text { AND } A T
$$

\section{Howard Hall, Providence, R. I.}

Seplember, 1gth, isth of 19th, 18ga.

GEORGE F: WILSON, Chaiman. ]

HENRY STAPLES, Secretary.

OBADIAH BROW Lे,

WILLIAM E, BARRETT,

A L ERED B. CHADSEY.

PLEASE CIRCULATE. 



\section{THE RHODE ISLAND SOCIETI}

FOR THE ENCOURAGEMENT OF

\section{DOMESTIC INDUSTRY}

Wxhibition, fattle thow and pair

\section{Narragransett Park, Cranston, Rhode Island,}

AND FOR

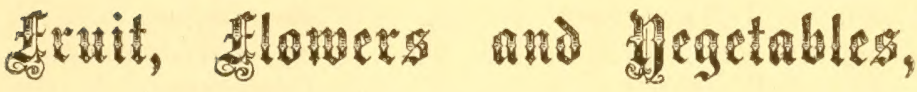

$\Delta T$

Howard Hall, Providence, $\mathbb{R}$. I.,

ON

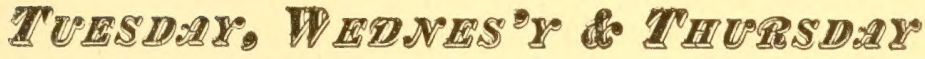

SEPTEMBER, $1 \%, 18$ \& 19, 18\%。

\section{OFFICERS FOR 1872.}

WILITAM SPRAGUE, $\left.\begin{array}{l}\text { JOSEPH H. BOURN, } \\ \text { CYRUS B. MANCHESTER, } \\ \text { OBADIAH BROWN, }\end{array}\right\}$ JOSEPH S. PITMAN, WILLIAM VIALL, EDWARD P. TAFT, ISRAEL M. BOWEN, J
President.

Vice Preisidents.

SECRETARY.

audit and Finance

CommitTeE. 


\section{STANDING COMMITTEE.}

OLIVER JoHNSON, Robert S. BURROUGH, JAMES $Y$. SMITH, ElisHA A. LAWTON Alfred B. ChADSEY, . Amasa Sprague, Henry Staples, William B. SPENCER, HenRY J ANGELL, George F. Wilson, Charles S. Bradley, James De W. Perry, Royal C. Taft, Silas Moore,

Aluen C. MatheWson, JOHN G. CLARKE, Lyman B. Frieze, ELISHa DYer

WiLliam E. BARRETT, Cyrus Harris, Joseph F. BROWN, Thomas G. PotTer, Albert C. Eddy, SuChet MaUran, 2D

William H. ALLiN, STEPHeN BRoWNELL, George Manchester, JOHN W. SAWYER, BERIAH H. LAWTON, William F. Channing,
Providence.

66

66

Cranston.

Wickford.

Cranston.

Barrington.

Phenix.

Providence.

East Providence.

North Providence.

Bristol.

Providence.

Cranston.

Barrington.

South Kingstown.

Providence.

“6

66

Warwick.

North Providence,

East Providence.

Providence.

66

Barrington.

Providence.

Portsmouth.

Providence.

North Kingstown.

Providence.

\section{EXECUTIVE COMMITTEE FOR THE EXHIBITION OF 1872 .}

George F. Wrison, East Providence, HENRy StAples, OBADIAH BROWN, Wililiam E. Barrete, Providence.

Alfred B. Chadsey, Wickford.
Barrington,

North Providence.
Chairman. Secretary. 


\section{RULES AND REGULATIONS.}

In case there should not be any competition on an article offered for a premium, the committee are authorized to withdraw the premium, unless the one article presented should, in the judgment of the committee, possess unusual merit.

No pool selling, or other form of betting or gambling shall be permitted on the ground, under penalty of expulsion from the ground.

The Executive Committee will use all diligence to insure the safety of stock, animals and articles, after being received and entered by their proper committees, but will not be responsible for any loss or damage that may occur. Exhibitors must give personal attention to their animals, and articles, and at the close of the exhibition attend to their removal.

No premium will be paid on any animal or article removed from the Exhibition before its close, unless the written consent shall be first given by the Executive Committee, and premiums not claimed within sixty days after the award, will be considered as forfeited.

All animals, or articles are arranged into Divisions, and persons offering either for premiums, will find a person in charge of each Division, to whom these articles must be delivered. Said person will wear a badge plainly denoting the Division under his immediate charge.

Tickets of admission will be as follows:

Single ticket, admitting one person once to the Park and to Howard Hall,

$\$ .50$

Children under twelve years of age,

One horse and rider, once,

One horse vehicle and driver, once, . . 1.00

Two " " " ". " . . . 1.25

Four " " " . . . 1.50

Each occupant of a vehicle, other than the driver, $\quad .50$

The exhibition of stock in the rings, and on the track, will take place precisely at the time specified; and animals not prepared at the proper time and place, may, at the discretion of the committee, be ruled out of competition.

For the convenience of exhibitors, stalls will be provided for stock. Hay, straw and water will be provided without charge, also, grain for swine and poultry. Grain for other purposes will be furnished at market price.

All entries for animals competing for premiuns, MUST be made at the Secretary's office, Railroad Depot, I'rovidence, R. I., on or before Monday, September 2d, 1872. All other entries for competition must be made as above on or before 
6 o'clock P. M., Saturday, September 14th, 1872. The Committee earnestly request that every article to be exhibited at the Park, shall be delivered there promptly on Monday, September 16th.

Arrangements have been made with all the Railroad Com. panies (excepting the Providence, Hartford \& Fishkill), to transport passengers and freight, during the three days, at half-price. The Hartford, Providence \& Fishkill Railroad Co. deduct thirty per cent on all regular fares when it is 50 cents or over. All under 50 cents, no deduction.

All animals must be owned in this State, and all articles must be grown or manufactured in this State, to compete for premiums.

\section{PROGRAMME.}

Monday, SePtember 15, 1872, DAY FOR COMPleting AR. RANGEMENTS.

The sub-committees are expected to make final arrangements for the exhibition of all the several articles offered for competion for premiums, at the Park, of articles belonging to their departments, to see that each article is in its proper place, and so arranged as to show all its qualities to the best advantage.

All the superintendents on articles at the Park will be on the ground at 4 o'clook, P. M., prompt, to respond to the calls of the Executive Committee, or for consultation with them.

Tuesday, September 16, 1872.

10 o'clock, A. M. An address by the President of the Society. 11 o'clock, A. M. Plowing Match, Division G.

12 o'clock, M. Dinner of the Society.

2 o'clock, P. M. Work to be commenced by sub_commit. tees of Division A, Class 1 and 2.

3 o'clock, P. M. Trial of speed of Horses, Division A, Class 3.

$4 o^{\prime}$ clock, P. M. Trial of speed of Horses, Division A, Class 4.

WEDNESDAY, SEPTEMBER 17, 1872.

9 o'clock, A. M. Announcement of awards of Tuesday.

91.2 o'clock, A. M. Sub.Committees at work on Divisions B, $\mathrm{C}, \mathrm{D}$ and $\mathrm{E}$.

1 o'clock, P. M. Sub-Committee at work on special premiums, Butter, Cheeso, Bread, and on Soaps. Fish, and Patents. Also, on Divisions H, J, K, L, M, O, P, Q, R, $\mathrm{S}, \mathrm{T}, \mathrm{U}, \mathrm{V}$.

2 o'clock, P. M. Sub.Committee at work on Division A, Class 5. 
21.2 o'clock, P. M. Division A, Class 6.

3 o'clock, P. M. Trial of speed, Division A, Class 7.

31.2 o'clock, P. M. Trial of speed, Division A, Class 8.

4 o'clock, P. M. Trial of speed, Division A, Class 9.

Thurdday, September 17, 1872.

9 o'clock, A. M. Announcement of Awards of committees of the previous day.

10 o'clock, A. M. Exhibition on the track of all horses and cattle that have received a premium.

11 o'clock, A. M. Trial of Working Teams and Oxen.

2 o'clock, P. M. Announcement of Awards of Division F,

2 o'clock, P. M. Division A, Class 10.

21.2 o'clock, P. M. Division A, Class 11.

3 o'clock, P. M. Division A, Class 12.

31.2 o'clock, P. M. Trial of speed, Division A, Class 13.

4 o'clock, P. M. Trial of speed, Division A, Class 14, 


\section{DIVISION A. HORSES.}

Superintendent: Colonel Amasa Sprague.

Class 1.-Stallions for general use, four years old and upwards, speed not considered.

First premium,

Second "

Third ".

$\$ 30.00$

20.00

5.00

Chass 2.-Geldings and fillies, three years old and under.

First premium,

Second "

Third "

$\$ 15.00$

10.00

5.00

Class 3.-Gentlemen's Driving Horses, that have never trotted better than three minutes, owners to drive; mile heats, best 3 in 5 , in harness.

First premium,

Second "

Third

“

Class 4.-For all horses that have never trotted better than 2.35 ; mile heats, best 3 in 5 , in harness.

First premium,

Second "

Third "

$\$ 250.00$

150.00

100.00

Class 5.-Stallions three years old, and under four.

First premium,

Second “

Third "

Class 6.-Matched Horses, for road or carriage, not less than 14 1.2 hands high.

First premium,

Second “

Third "

Cuass 7.-Gentlemen's Double Teams, that have never trotted for money; best 3 in 5 .

First premium,

Second "

Third "

$\$ 20.00$

$15.0)$

10.00

$\$ 40.00$

20.00

10.00

Class 8.-Four years old and under; mile heats in harness.

First premium,

Second "

Third "

Class 9.-For all horses that have never trot ed better than 2.50 ; mile heats, best 3 in 5 , in harnc is.

First premium, 


\section{GEORGE W. WRIGHT,}

\section{ONE PRICE}

\section{WHOLESALE AND RETAIL}
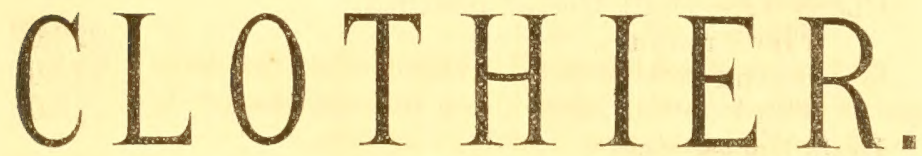

EXCLUSIVE SALE FOR PROVIDENCE OF

DEVLIN \& CO.'S FINE CLOTHING,

OF NEW YORK, AND

MACULLAR, WILLIAMS \& PARKER,

$$
\text { OF BOSTON. }
$$

Fine Clobing Made bo Order.

53 \& $5 \%$ Westminster, 1 \& 3 Exchange St.,

$$
\text { P ROVIDENCE, R. I. }
$$


Second "

Third "

CuAss 10.-Stallions two years old, and under three.

First premium,

Second "

$\$ 15.00$

10.00

Third "

Class 11.-Mares with foal by their side, or that had previously had a foal.

First premium,

Second "

Third

Class 12.-Draft Horses, matched.

First premium,

Second "

Third "6

Draft Horses, single.

First premium,

Second "6

Third "

CLASS 13.-For horses that have never trotted better than 2.45 . mile heats, best 3 in 5 , in harness.

First premium,

Second "

Third "

Class 14.-For all horses; best 3 in 5 , mile heats, in harness.

First premium,

Second "

Third "

100,00

All horses entered for Premiums must be owned in this State.

In each and every trial for speed, a payment of ten per cent on the amount of the entire purse trotted for, must be paid at the time of entry. Three entries, at least, must be made for each premium for trial of speed, and two horses must start.

The trotting will be conducted under the rules and regulations of the National Association for the promotion of the interests of the American Trotting Turf. State.

All animals offered for premiums must be owned in the 
C. EARLE WHITAKER, No. 48 North Main Street,

FPIOUIDIFTORE, IF. I.

IMPORTER OF, AND

WHOLESALE AND RETAIL

DEALER IN

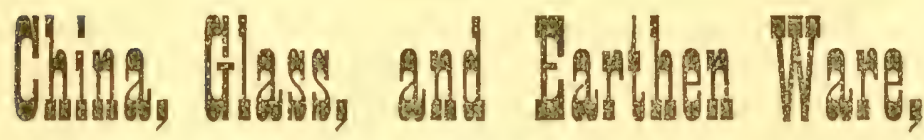

IVORY AND COMMON CUTLERY,

Silver Plated Knives, Forks,

Spoons, Castors, Ladles,

Butter Knives, Sali

Spoons, \&C.

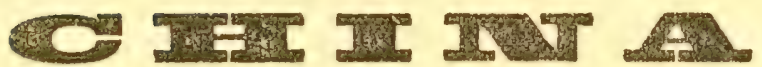

DECORATED TO PATTERN IN FULL. SETTS, OR MATCHINGS.

\section{RICH GLASS WARE}

CUT TO ORDER, WITH MONOGRAMS, IN-

ITIALS. OR ANY DESIRED DEVIUES.

\section{PICI FANCY TOLLT SIITS,}

\&c., \&c., \&c., \&c., \&c., \&c., \&c. 


\section{DIVISION B. CATTLE.}

Superintendent: Joseph F. Brown.

Class No. 1. Pure Breed.

Deyonshire, Short Horn, Ayritire, Jersey, Dutch or HOLSTEIN.

Bust Bull, three years old and uprards,

Second best " " " " $\$ 25.00$

Best Bull two years old and under three years,

Second best,

Best Bull one year old and under two years,

Second best,

Best Cow four years old and upwards,

20.00

Second best,

Third

10.00

Best Cow 3 years old and under four years,

Second best,

'Third

Best Heifer two years old and under three years,

Second best,

Third "

Best Heifer under two years old,

Second best,

Best thoroughbred Bull of any class,

The Committee on Pure Breeds will require full and satisfactory pedigrees in every instance.

Auimals competing for siugle Preminns can also compete for Herd Premiums, or for Sweepstakes.

\section{Herd Premiums.}

Best Bull, and not less than five Cows or Heifers; not less than two years old, belonging to the same person,

Second best, and not less than five Cows or Heifers; not less than two vears old, belonging to the same person,

Third best, and not less than five Cows or Heifers; not less than two years old, belonging to the same person,

Best Cow, three years old and upward, grade and native,

Second best,

Best Heifer, two years old and upward, grade and native, 


\section{BARKER, WHITAKER \& CO.,}

Nos. 20 \& 24 Westminster Strect,

PROVIDENCE, R. I.

NAILS; GLUE; ENERY ; TWINES; JEWEIERS' FILEA AND TOOLS; CAST S'TELL, ILUN, BRASA AND COPPER WIRE; RINGS AND RING TRATELERS; I'LAIN AND SWIGED COMB PLATL; URUA, SPINDLE ANI LUOP BANDING ; AND

\section{Manufacturers' Supplies Generally.}

A gents for the sale of Leather and Rubber Belting, Self-Lubricating and Rubber Steam Packing, Rubber and Linen Hose, and American File Co.'s Files, \&c. Also, for

\section{FAIRBA NK's}

Patent Hay, Coal, Railroad, Platform

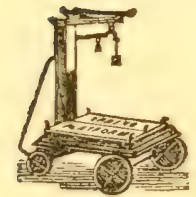

William Whitaker, Frederic A. Barker,
AND COUNTER

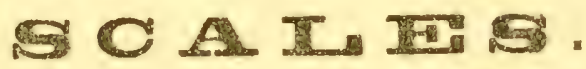

Wm. Cyrus Barker. George H. Chadsey. 
Best Milch Cow of any Breed, $\quad 25.00$

Best yoke of Oxen, four years old and upward. $\quad 20.00$

Second best, $\quad 15.00$

Third " 10.00

Best yoke of Steers, three years old and under four, $\quad \mathbf{1 5 . 0 0}$

Second best, $\quad 10.00$

Third best, $\quad 5.00$

Best yoke of Steers, under three years old, $\quad 8.00$

Second best, $\quad 5.00$

Third "6 3.00

Best fat $\mathrm{Cx}_{\mathrm{x}}, \quad 15.00$

The best Oxen, not less than ten pairs from any one Town,

Herd Premiugr.

Best six Cows or Heifers, not less than two years old, belonging to the same person,

Second best, not less than two years old, belonging to the same person,

Third best, not less than two years old, belonging to the same person,

\section{DIVISION-C.-SHEEP AND HOGS.}

Superintendent: Beriah H. Lawton.

Class No. 1. Pure Breeds.

Southdown, Leicester, Cotswoud, Pure Merino.

Best Buck, three years old and upward,

Second best, three years old and upwards,

Best pen of Ewes, not less than six, four years old and upwards,

Second best,

Best pen of Ewes, not less than six, not less than two years old,

Best pen of Ewes, not less than six, under two years of age,

Second best,

GRADE AND OTHER BREEDS NOT ENUIERATED ABOVE.

Best Buck, three years old and upward.

Second best,

Best pen of Ewes, not less than six, four years old and upward,

Second best, 


\section{CLEVELAND \& BROS.}

Manufacturers and Dealers in
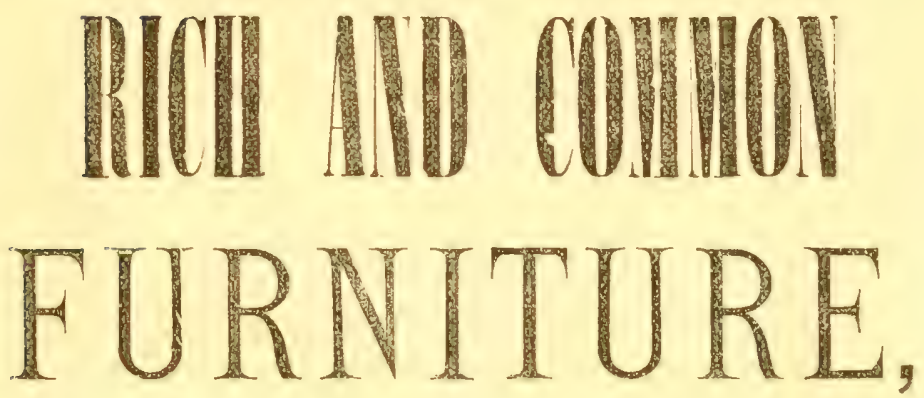

Han Methom
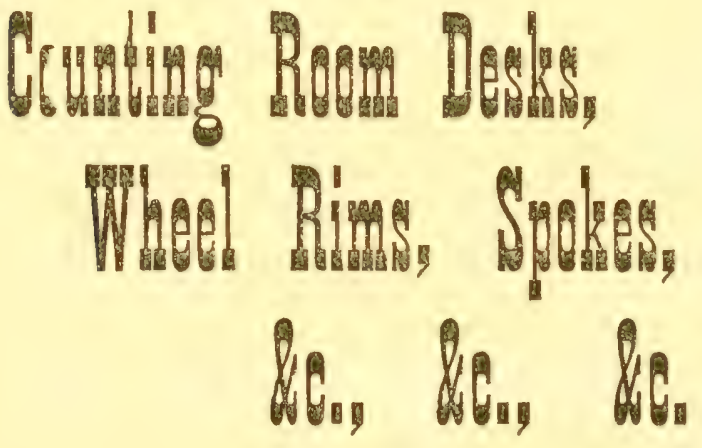

ALSO, ALL KINDS OF

GIG SAWING AND TURNING DONE TO ORDER.

Ware Room, 110 North Main Street. Manufactory, 13 Mill Street. 
Best pen of Ewes, not less than six, not less than two years old,

Second best,

Best pen of Ewes not less than six, under two years of age,

Second best,

\section{HOGS.}

Best Boar, over one year old, LARGE BREED, $\quad 10.00$

Second best,

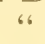

5.00

Best Breed Sow, over one year

“

10.00

Second best,

“

Best pen of Shoats, not less than four, and not less than six months old, LARGE BREED,

10.00

Second best,

Best litter of pigs, not less than six, LARGE BREED,

10.00

Second best,

Best Boar, over one year old, Shall Breed,

Second best,

10.00

5.00

Best Breed Sow, over one year,

Second best,

Best pen of Shoats, not less than four, and not less than six months old, Syald Breed,

Second best

"B

10.00

5.00

Best litter of pigs, not less than six,

Second best,

5.00

DIVISION D. POULTRY.

Superintendent: Royal D. Horton,

Best pair dark Brahmas,

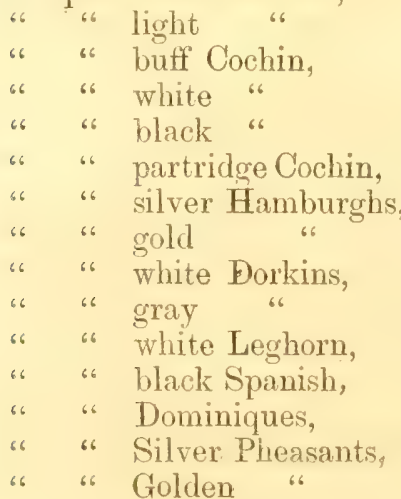




\section{G. C.P. HUTCHMS:}

Corner of Dorrance and Weybosset Sts.,

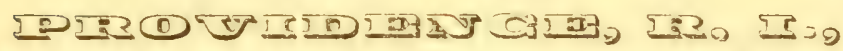

Tatie this method of informing the pubtic that they continue to sell the very best goods in their. line at as low prices as can be afforded. Our stock embraces a large assortment of
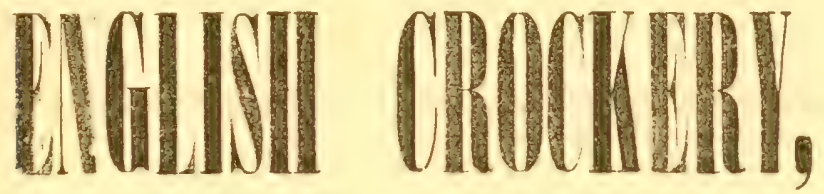

FROM. THE BEST MANUFACTURERS.
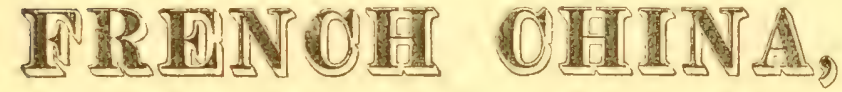

Both White and Decorated, from the celebrated manufactory of Messrs. Haviland \&. Co., Limoges, France, nearly every piece of which is made to our order and imported expressly for our own trude. Alsos a full line of

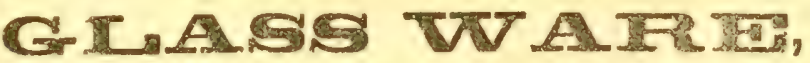

both imported and domestic, and the largest assortment of

\section{Gas and Kerosene Fixiures}

in the State. Also, a large assortment of the best quality of

\section{\&DIER PEAED WARE}

together with an endless variety of FANCY GOODS and TISES, which we offer at wholesale and retail.

Downer's Geiluine Kerosene Oil in quantities to suit. 
Best pair Houdans,

" " of any other pure breed,

" " improved barn-yard,

" " "Geese.

" " Turkeys,

" " Ducks,

Best and largest exhibition of Pigeons, not less than five varieties,

Best and largest exhibition of live birds, not less than ten varieties,

Best and largest exhibition of poultry by one exhibitor, not less than ten varieties,

\section{DIVISION E.-DAIRY, AGRICULTURAL PRODUCTS, \&C.}

Superintendent: Thomas G. Potter.

Best package of ball butter, not less than ten pounds, $\$ 5.00$ Second best,

Best package of tub butter not less than 25 pounds, $\quad 5.00$

Second best, 3.00

Best cheese not less than sixteen pounds,

Second best,

Best exhibition of Honey,

Second best,

Best sample Wax,$$
\text { (6) }
$$$$
66 \quad 66
$$

"6 6

Corn

2.00

$66 \quad 66$

Barley

66

2.00

$86 \quad 66$

Oats

2.00

66.66

Wheat "

2.00

. " "Timothy "

2.00

$66 \quad 66$

R. I. Bent "

2.00

Best collection of Garden Seeds,

\section{SPECIAL PREMIUMS.}

All gonds entered for these premiums will not be allowed to enter for any other premium.

BUTTER.

Premiums offered by Messrs. Parsons, Bugbee \& Co., wholesale srocers, 26 to 34 Canal St., Providence, R. I. Best package of Butter, not less than 50 pounds, to be made in this State, 


\section{H. E, BARNEY \& SON,}

Dealer's in first-class
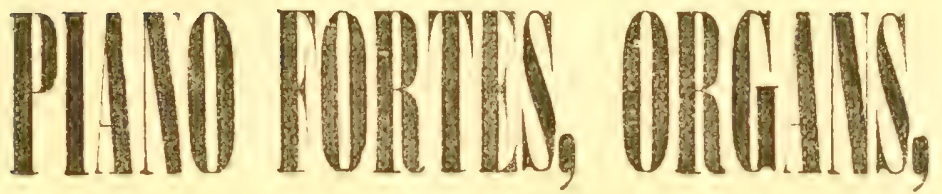

A IV 1

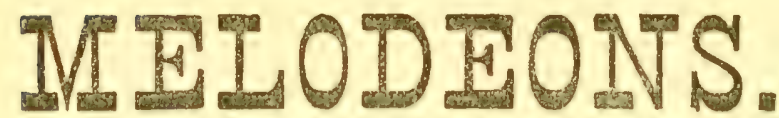

Second-hand Pianos for sale and to rent.

Pe Piano Forte tuning, repairing and polishing.

\section{WI A I.}

173 Westminstor St.

Comner of Fiddy. 
Second best package of Butter, not less than 50 pounds, to be made in this State,

CHEESE.

Premiums offered by Messrs. Waldron, Wightman of Co., whole. sale grocers, 7 to 15 Pine St., Providence, R. I.

Best Cheese, to weigh not less than 16 pounds, to be made in this State,

Secoud best Cheese, to weigh not less than 16 pounds,

to be made in this State,

\section{WHITE BREAD.}

Premiums offered by Messrs. Barden \& Keep, four dealers, No. 19 Exchange Place, Providence, R. I.

Best loaf of White Bread made by a Rhode Island lady not over twenty years of age,

Second best,

\section{BROWN BREAD.}

Premiuns offered by Messrs. Rice \& Hayward, bakers, 434 Broad St., Providence, R. I.

For the best loaf of Brown Bread made by a Rhode

Island lady not over twenty years of age,

Second best,

\section{SOAP.}

To be exclusively of Rhode Island manufacture.

Best exhibition of Harl Soap,

Second best,

Best exhibition of Toilet Soap,

Second best,
Silver Medal.

Diploma.

Silver Medal. Diploma

\section{FISE.}

Best quiutal of Cod Fisl cured in Rhode Island,

Best tub of Mackerel

$\$ 10.00$

Best dissertation on Fish Culture,

PATENTS.

For the most useful mechanical improvement made within the last two years, by a citizen of Rhode lsland,

Second best, Third best,

Silver Medal. Bronze Jledal. Diploma. 
HUITIUR.

IN ORDER TO MAKE A BETTER DISPLAY $-O F-$

THEIR GOODS, Curry, Richards \& Anthony,

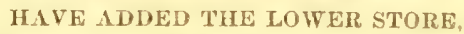

No. 116 W WESTMPNSTER STREET,

To their already Extensive Warerooms, and stocked the same with a varied assortment of
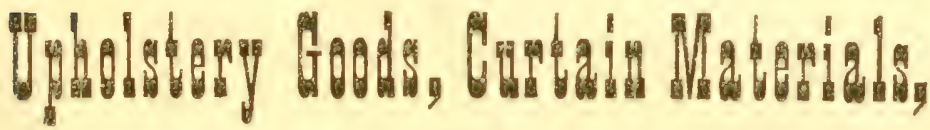

$$
-\mathrm{AND}-
$$

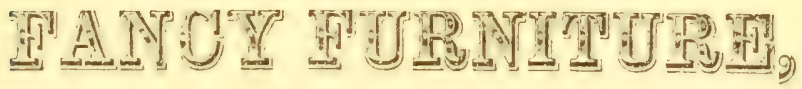

to which they invite the attention of purchasers. They hare also connected the different thoors of their establishment with a

PATENT SAFETY PASSENGER ELEVATOR, for the accommodation of their customers, thus enathing them to examine the Eutire Stock throughout the building, consisting of erery grade of

\section{DRAWING-ROOM, LIBRARY, DINING- ROOM, HALL AND CHAMBER FURNITURE,}

with ease and comfort.

CURRY, RICHARDS \& ANTHONY, $116 \& 119$ Westminster Street, P R Q U I D E 
DIVISION F. FRUITS, FLOWERS AND VEGETABLES.

The exhibition of these articles will be held in Howard Hall, Providence, R. I.

Superintendent: Arthur F. Dexter.

Assistant " : Charles H. Phillips.

\section{APPLES.}

Best collection, five specimens of each variety, $\$ 10.00$ Second

8.00 Third

Best eight variet's " Second "

Best five " " "6

Second " " "

66
66
66
66
66
66

6.00

5.00

4.00

4.00

3.00

Best single dish twelve specimens of one variety, $\quad 3.00$

Second " " " " "

Best ornamental basket of apples, mixed rarities, $\quad 3.00$ Secoud "4 "6

\section{PEARS.}

Best collection, ĥve specimens of each variety, Second ". Third Second "

Best eight variet's ".

Best five "6 $\quad$ "6

66
66
66
66
66

10.00

8.00

6.00

5.00

$+.00$

4.00

3.00 Second 6.

Best dish, trelve specimens, of Bartlett's,

2.00

Best basket, assorted varieties,

any othor variety, Second " 66

$2 .(30$

\section{PEACHES.}

Best collection, five specimeus of each variety, Second "

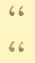

66 'Third 66

\section{QUINCES.}

Best peck of one variety, Second 66 6

HOT' HOUSE GRAPES.

Best collection of not less than six varieties. one bunch of each,

Second best collection of not less than six rarieties, one bunch of each,

Third best collection of not less than six varieties, one bunch of each, 
Mistablished 1833.

\section{OLIVER JOHNSON \& CO,}

Emporters and Manufacturers of

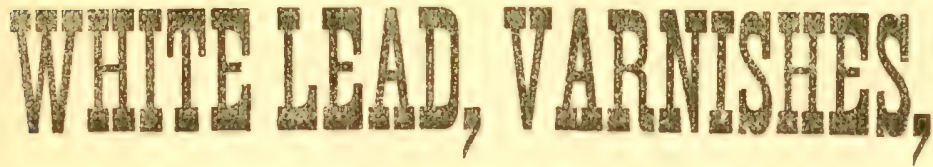

A N D

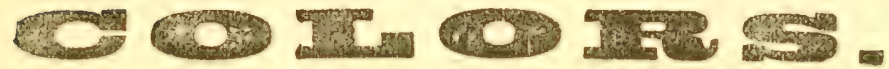

Dealers in

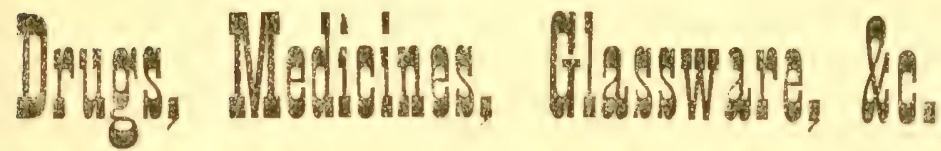

OFFICE AND WAREHOUSE, 13 AND 15 EXCHANGE ST., PROVIDENCE, R. I.

S Making the grinding of Lends and Colors a specality, we atre enabled to offer inducements not to be found in this State.

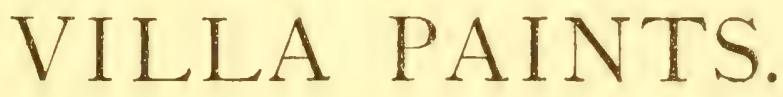

The most economical and durable paints nade, allapted to ontside and inside use. 
Best two varieties, two bunches of each, . $\quad 4.00$ Second " " "

Best two bunches Black Hamburg, $\quad 3.00$ Second " " " " " 2.00

Best two bunches Muscat of Alexandria, $\quad 3.00$ Second " " " " 2.00

Best two bunches of any other variety, $\quad 3.00$ Second " " " " " " " 2.00

\section{NATIVE GRAPES.}

Best collection, one bunch of each variety, $\quad 3.00$ Second " " " $\quad 2,00$

Best four bunches of any variety, $\quad 2.00$ PINE APPLES.

Best three specimens in Pots,

\section{FLOWERS.}

Best design for dinner table,

$\begin{array}{lll}\text { Second "6 "6 "6 } & \\ \text { Third " } & \text { " }\end{array}$

Best wall piece,

Second "

"

Third " "

Best arranged Basket of Flowers, Second "

"6

Fourth " " " "

Best two Table Boquets, Second "

Third "

Best two Hand Boquets,

Second "

Third

Best Bouqet, promiscuously arranged, Second "

Best collection of cut Flowers,

Silver Medal.

3.00

2.00

Silver Medal.

3.00

2.00

Silver Medal.

4.00

3.00

2.00

Silves Medal.

3.00

2.00

3.00

2.00

1.00

3.00

2.00

Second "

Sitver Medal.

4.00

2.00

Third

“

3.00

Second "

Best twelve varieties of Asters, single flower,

Third

Best six

Second "

"6 "6

1.00

3.00

Third "

66.66

2.00

Best twenty varieties of Dahlias,

Second " 


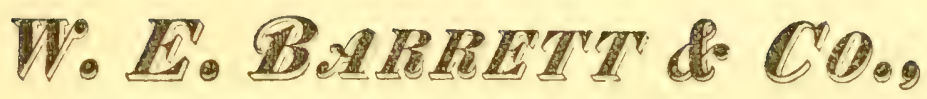
Manufacturers of Agricultural Implements, AND WHOLESALE DEALERS IN

\section{Farming Tools and Seeds}

OF ALL KINDS.

PARTICULAR ATTENTION IS CALLED TO OUR

CONICAL PLOWS, CONICAL HORSE HOES, HARROWS, CULTIVATORS, WHEEL BARROWS, STORE TRUCKS, HAY CUTTERS, CORN SHELLERS, $\& C ., \& C$.

AS BEING TIE BEST IN TIIS OR ANY OTHER MARLET: WE HAVE 'THE AGENCY ALSO OF THE

\section{Now Epragu Mower?}

The Bay State Wheeleed Horse Rake,

THE MATRACAREETE AXE,

AND OTHER FIRST-CLASS GOODS.

\section{CALL AND SEE US,}

$$
\text { - AT - }
$$

44 Canal Street, Providence, R. I. 
Best six varieties of Dahlias, $\quad 3.00$ Second " " " " $\quad 2.00$ Third " " " 400

Best twelve varieties of Gladolia single Spikes, S. Medal. Second " Thiird

Best six "6 "6 3.00

Second "s 64 " " 6 3.00

Best single Spike 2.00

Best twenty varieties of Verbenas, single truss of each, Silver Medal.

Second best twenty varieties of Verbenas, single truss of each,

Third best twenty varieties of Verbenas, single truss of each,

Best six varieties of Verbeuas, single truss of each, 3.00 Second " "6 2.00

\section{PLANTS IN POTS.}

Best twelve Stove and Green-house plants, different varieties,

Second " " "

Third " "

$\begin{array}{llr} & & \$ 12.00 \\ \text { "6 } & \text { " } & 8.00 \\ & & 6.00\end{array}$

Best six Stove and Green-house plants, different varieties,

Second

Third "

" 6

Best eight Plants in bloom,

Best six variegated Plants,

Second "

Third "

Best single specimen,

Best six Ferns,

Second "6 "6

Third " "

Best six Lycopodiums, $\quad 4.00$

Second "

Third " "

Best six Caladiums,

Second "

Third

“

2.00

\section{VEGETABLES.}

Best collection Vegretables, 


\section{W.S. ITHWID,}

Wholesale Dealer in

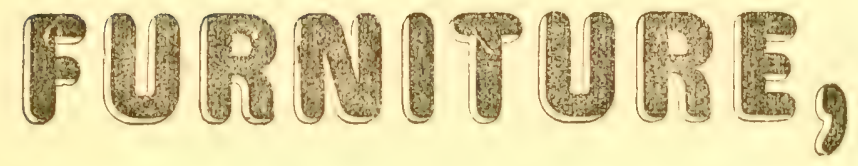

1000den Vare,

MATCHES,

Paper and Paper Bags.

NO. 49 CANAL ST.

Providence, R. I. 
Best twelve Long Red Beets, $\quad 2.00$ Second " " " "

Best two heads Cauliflowers, $\quad 2.00$

Second " " " $\quad 1.00$

Best three heads Cabbage, $\quad 2.00$

Second " " " "

Best single " " $\quad 1.00$

Best twelve Long Orange Carrots, $\quad 2.00$

Second " " " $\quad 1.00$

Best three heads Celery, $\quad 3.00$

Second " " " " 2.00

Best twelve ears Sweet Corn, $\quad 2.00$

Second " " "

Best peck of Onions, $\quad 2.00$

Second " " 1.00

Best peck of Squash Peppers, $\quad 2.00$

Second " " " " 1.00

Best peck Potatoes, $\quad 2.00$

Second " " 1.00

Best half peck Potatoes, of any new variety, $\quad 2.00$

Second " " " " " " 400

Best Ergg Plant, $\quad 2.00$

Second " " $\quad 1.00$

Best two Turban Squashes, $\quad 2.00$

Second " " " "

Best two Marrow " " 2.00

Second " " " " $\quad 1.00$

Best two Hubbard "“ 2.00

Second " " " $\quad 1.00$

Best two Pumpkins, $\quad 2.00$

Second " " 1.00

Best peck Lima Beans, $\quad 2.00$

Second " " 1.00

Best peck Tomatoes, $\quad 2.00$

Second " " 2.00

Best peck Cranberries, raised in the State, $\quad 2.00$

Second "6 " " " 1.00

Best twelve Parsnips, $\quad 2.00$

Second " " 1.00

Best six Turnips, $\quad 2.00$

Second "6 " 1.00

Best three Water Melons, $\quad 2.00$

Second " " " 1.00

Best three Musk Melons, $\quad 2.00$

Second " " " 1.00 


\section{CARRIAGES FOR SALE.}

Having greatly incressed my facilities for prosecuting the

\section{CARRIAGE BUSINESS,}

I now offer to the public the largest assortment of Carriages ever before on exhibition in lihode Island, consisting in part of the following:

Four and six-seat Rockaways with shifting parti-

tions, American Family Earouches, Ameri-

can ParkPhatons, Franch Cabrioless

Family Carryalls, Sun Tops, for

two or four persons, Beach Wagons

with shifting seats, Fhxetons, Top Bugies,

Pony and half Pony Phatons, open Eugies,

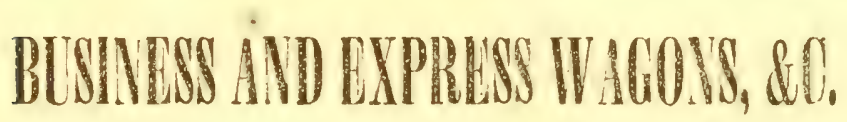

Which I propose to sell on

\section{MORE FAVORABLE TERMS}

Than any house in the State, and parties who wish to purchase should call and examine my stock before making their selections, as they will tind all of the latest atyles for designs, heauty and elegance in finish, excelling aything that can be found in the market.

\section{CHARLES H.WEST,}

Arsenal Lane, rear of Old Providence

Hotel, and between North Main and Benefit Stretts, Providence, R I. 


\title{
DIVISION G.-TRIAL OF PLOUGHS AND PLOUGHING MATCH.
}

\author{
Superintendent: James D.W. Permy.
}

Best ploughing, one-eighth of an acre with two pair of cattle,

Senond best,

Thire "

8.00

5.00

Fourth "

3.00

Best ploughing, one-eighth of an acre with one pair cattle,

Second best,

Third "

10.00

8.00

5.00

Fourth “

Best ploughing, one-eighth of an acre for horses,

10.00

Second best,

Tlind ".

8.00

5.00

Funith "

3.00

The furrows to be cut not less than seven inches deep for double team, and not less than six inches deep for single team.

The trial of ploughing will commence at 11 o'clock on Tuesday, September 16th.

\section{DIVISION G.-AGRICULTURAL IMPLEMENTS.}

Superintendent: Amasa H. Eaton.

Premiums for the following will only be awarded to those articles manufactured in this state.

Best Howing Nachine,

"Reaper,

" Plow,

" Corn Sheller,

“ Threshing Machine,

“ Vegetable Cutter,

"Seed Sower,

" Grist Mill,

“ Cider Mill,

“ Hay Press,

" Cheese Press,

“ Haud Barrow,

"Hand Truck, $\$ 10.00$

10.00

5.00

3.00

5.00

3.00

3.00

10.00

3.00

5.00

3.00

3.00

3.00

"Ox Shorel,

" Garden or Field Roller,

" Lawn Mower, 


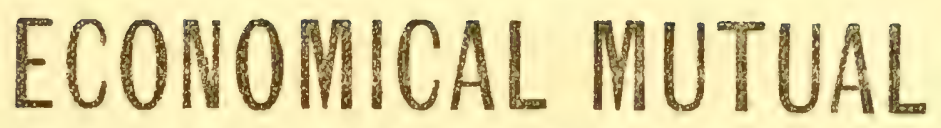

\section{Life Insurance Company,} PROVIDENCE, R. I,
SIMON S. BUCKLIN, C. G. McKNIGHT,
President.
Vice-Pregident.

HON. ELIZUR WRIGHI', Actuary.

WM. Y. POTPES,

Secrctary.

ALFX. FARNUM, Gen. Superintendent of Agencies.

Policies in force

$\$ 5,459.361 .00$

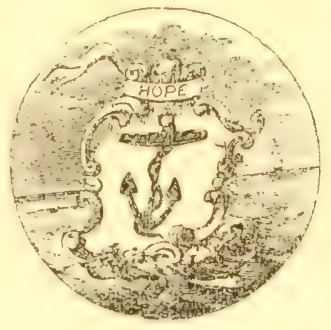

Assets,

\section{ADV ANTAGES.}

\$9005,801.00.

I. Absolute security from loss. If for any reason the premiums are not paid when due, a paid-up policy will be issued for at least the amount of premiums paid, and in some instances for nearly three times that amouut. This is the only Company that raakes all policies absolutely non-forfeitable FROM THEIR IMTE.

II. No extra charge on the lives of females.

IIl. Free permits to officers of the Army and Navy.

IV. Ne restriction whatever upon residence or travel.

V. These results are suftieiently guaranteed by the fact that the affairs of the Company are managed by a livard of Directors comprising some of the best financial talent in Now England, numbering among others, Hon. Wm. Spraglie, Hon. H. B, Anthony, Hon. Elizur Wright (Aetuary), Gen. A. E. Jiurritle, Simon S. Bucklin (l'residenti, Isaac H. Soutluwick, Earl T. Mason,

Tha attention of experienced solicitors is invited to the plans of this Company. which are brietly euumerated above, and which make it a particularly desirable Company to eanvass for.

Applications fur District Agencies from those who propose to solicit personally and energetically will be sectived and favorably considered by the General Agents.

$\Lambda$ few oompetent and reliable General Agents are wanted for unoccupiet? fields, with whom liberal arrangements will be made.
C. G. MeKNIGHT, General Agent for $R$. $I$.
N0. 45 WESTIINSTER STRETT,
Providenco, R. I. 
Best doxen Garden or Hay Rakes, $\quad 3.01$

" dozen Shovels or Spades, $\quad 3.00$

" Grain Cradle, $\quad 3.00$

" dozen Scythes and Snathes, $\quad 3.00$

" dozen of Axes, $\quad 3.00$

" collection of Agricultural Implements, 20.00

\section{DIVISION S.-VEHICLES AND HARNESES.}

Superintendent: Charles F. Eaton.

Premiums for the following articles will only be awarded to those articles manufactured in this State.

Best Family Carriage,

"Top Buggy,

" Open Bugry,

"Chaise,

"Sleigh,

" Farm Wagon, for two horses,

" " for one horse,

"Or Cart,

" Horse Cart,

" display of Vehicles,

" Double Harness,

“ Buggy Harness,

" Chaise Harness,

" single work Harness,

" double work Harness,

" Cart Harness,

Diploma.

- display of Harnesses,

66

\$6

66

66

66

6

66

$\$ 25.00$

Diplomx.

66

66

66

66

66

$\$ 10.00$

\section{DIVISION K.-LEATHER AND RUBBER.}

Superintendent: George Manchester.

Best Leather Trunk,

" " $\quad$ Valise,
"
" pair of sewed Boots,
" " $\quad$ " $\quad$ shogged Boots,
" " $\quad$ " $\quad$ Ladies Shoes,
" " farmer's working Shoes,
" Leather Belting,

Diploma. 


\section{Gean's Furmishing Goods.}

\section{Geo. R. Whipple,}

No. 7 Westminster Street.

Gents' Merino Shiris and Drawers, Scarfs, Ties, Kid, Buck, Dog Skin and Lile Gloves, Horse Blankets, Carriage Robes, Merino and Cotton Hosiery, also, all the new siyles of Hats, Caps, \&c. constantly on hand.

\section{Something New.}

\section{Baker's Patent Harness}

\section{Saddle Pads.}


Best Rubber Belting,

" Rubber Huse,

“ pair Rubber Boots,

" pair Rubber Shoes,

" display of Rubber Goods,

" display of Leather Goods,

Diploma.

66

66

$\$ 10.00$

10.00

All goods competing for Premiums must be of Rhode Island manufacture.

\section{DIVISION L.-BINDING, PRINTING \&C.}

Superintendent: John G. Clarke.

Best specimen of Fancy Binding, bow ne magazine, Diplemu.

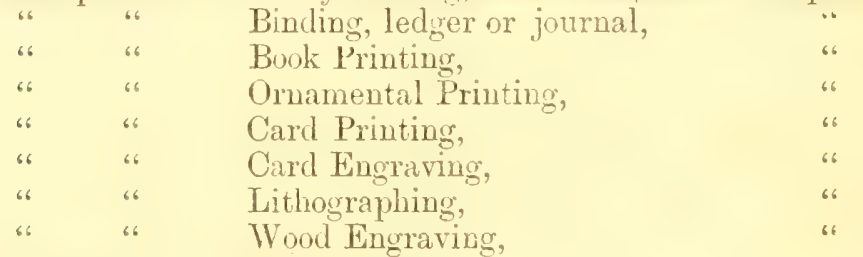

Each specimen to be done in this State.

\section{DIVISION M.-HOUSEHOLD FURNITURE, \&C.}

Confined exclusively to articles manufactured in R. Island.

Superintendent: Stephen Brownell.

Best set of Parlor Furniture,

" " Clitmier "

" " Kitcien "

" one dozen of Brooms,

"6 " Floor Brushes,

" " $\quad$ Feather Dusters,

" ' Clothes Brushes,

" specimen of Wooden Ware,

Diploma.

" exhibition of Furniture,

“

" display of House Furnishing Goods, 


\title{
GEO. F. YOUNG \& CO.,
}

\author{
MANUEACTUIERS AND DEATERS IN
}

Cigars, Tobacoos, Pipes \& Snuviffs.

Proprietors of the Celebrated Brands

Up an Up and Monument Cigars,

UP AN UP NAY AYB UP IY UP HIE CUT CHEWIYG.

9 Westminster Street,

PROVIDENCE, R. I.

F, ALLEIN \& CO,

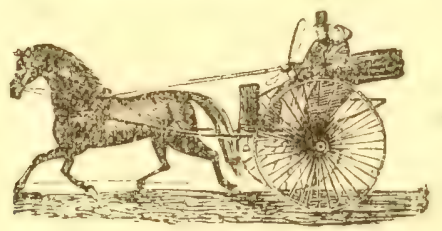

IIANUFACTURERS AND DEALERS IN

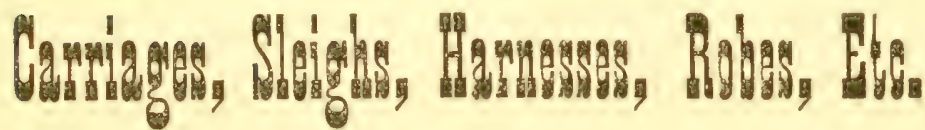
№. 3 Fulton St., Opp. City Hall. PROVIDENCE, R. I. 
DIVISION N. CARPENTEF'S AND COOPER'S WORK.

Superinteudent: Clifton A. Hall.

Carpenter work must not have more than one coat of paint. Best plain panel Door,

" ornamental "

"Window Sash,

"Window Blind,

" exhibition of Sashes, Doors and Blinds,

" made Barrel,

" "Tub,

" " Firlin,

" " Bucket, Diploma.

display of Cooper's work,

66

66

$\$ 15.00$

Diploma,

6

66

$\$ 5.00$

All articles competing for Premiums must bo of Rhode Island manufacture.

- DIVISION O.-HARDWARE, \&C.

Superintendent: Albert C. Eldy.

T'o be exclusively of Rhode Island manufacture. Best Cut Nail,

"Horse Shoe,

"Window Spring,

"Blind Fastener,

" set of Carpenter's Tools,

" display of Cutlery,

Second best,

Best display of Heavy Hardware,

Second best

Best display of Light Hardware,

Second best

Best display of 'linware,

$\begin{array}{lll}" 6 & \text { " } & \text { Copper Ware, } \\ " & \text { " } & \text { Iron Ware, } \\ & & \text { Japanned Ware, }\end{array}$

Diploma.

6

66

66

Silver Medal.

Bronze "

Silver " "

Bronze "

Silver "

Bronze "

Silver "

$66 \quad 66$

“6

Diploma. 


\title{
RURAL BOOKS,
}

\section{FOR SAIE BY}

\section{George H. Whitney,}

\section{No. 3 Westminster St.}

\author{
PROVIDENCE. R. I.
}

Af Any Book on this list will be forwated, postpaid, to any aderess in the Unitred States, on receipt. of the price.

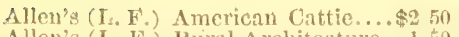
Allen's (L. F.) Ruril Architecture. 150 Allen's (R.L.) American Farm Book 150 Allen's New American Farm Book,. 250 Allen's Diseases of Dom. Animals.. 100 American Bird Fancier............ 30 Americau Rose Culturist...... 30 American W eeds amd Useful Plants. 1 7. Bement's Rabbit k'ancier........... 30 Bommer's Method of mak'g Hanures 25 Boussingault's learal Economy...... 160 Breck's New Book of Fowers........ 17.5 Buist's Flower Garden Directory... 150 Buist's Family Kitchen Gartener.... 100 Baldwell's Agric. Chem. Analysis... 2 00 Chorlton's Grane Grower"s Guide... 7.5 Cobbett's American Gardener....... Cole's (S. W. American Frtit Book. Cole's Veterinarian.................

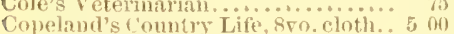
Dadi's (G.II.) Modern Iforse Ioctor 150 Dade's American Cattle Doctor..... I 50 Datma's Muck Mitmuil.............. 1 a.j Darwin's Variation of Animals and

Plants under Domestication, 2 roly. 600 bog \& Gun, (110oper's). lla. 30e., clo. 60 Downing's Fruits is Fruit Trees, 850. 750 Downing's Landscape Gardening... 650 Draining for Profit and Health...... 150 Eastwood on Crauberry.......... 75 Elliott's West'n Fruit Grower's Guirle 150 Farm Impl'ts \& Machinery (Thomas) 150 French's Farm Drainage............ 150 Field's (Thos. W.) Pear Culture.... 125 Fuller's Grave Culturist.......... 1 50 Fuller's small Fruit Culturist...... 150 Fuller's Strawberry Culturist......

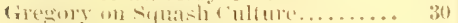
Guenori on Milch Cows............ 75 Harris Insects Injurious to Vegetation, ext, clo ..................4 400
[Tenderson's Gardcuing for Profit... 1 5ot fiendewon's I'ractical Formoulture.s1 for Herbert's Hints to Horse-Keevers.. I it In rulture................... 10 Jagues' Manual of the House...... 1 .in Johnson's Ifow ('rops Grow......... 2 wit Jolunson's How erops Feerl........ '2 lift Johuson's Peat and its Uses......... 1 1.5 Johnson's Apricullural Chemistry, . l $7 .$. Johnson's Elements of $\Lambda$ ir. Clemist'y 1 in Market Assistant (De Voe)........ it! liiles on the Horre's Foot.......... in Mohr on the Gratue Vine............. 1 bil Norton's Scicntific Agriculture..... i. Onion Cuiture.................... Our Farm of Four Acres, pa. 30., clo. ti: Pardec on Straw berry Culture..... i. P'ercherun Hurse..... Quinby's IIysteries of Bee-Keeping. 1 5.1 Randall's Sheef Husbandry ........ 1 s, Randall's Fine Wool Sheep II nsban'y 1 it lachardsom on the Dog, pa, 30., clo. i; Rnral Church Arehitecture..........12 Samders' Domestic 1'oultry, paper.. fir Schenck's Gardener's T'ext Bonk... Stewart's (John) Stable Brook...... 1 iil Thomuson's Food of Animals....... 1 thit T'm isunker Payers............... 1 .it Warler's American Pomology...... 3 (ii) IV arder"s Ifedwes and Erergreens... 150 Woodivard's Cottares \& litum-houses 1 .ju Woodware's Suburban and Country

Houses..................... 1 in IVoodward's Country Ifomes...... 1 , in Wheeler's Inural Homes........... 2 our Wheeler's Homes for the People... 3 3 ii Fouatt and spooner on the IIorse... 1 bo You-ti and Nartin on Cattle....... I 5n Youatt on the Hos.............. 1 (s) Youatt on Sheen................... I of 


\section{DIVISION P.-PAINTS, OILS AND CHEMICALS.}

'To be manufactured in Rhorle Island.

Superintendent: Henry J. Angell.

Best White Lead, dry,

Second best

Silver Medal. Diploma.

Best White Lead, ground in oil, Second best Silver Medal. Diploma.

Best Zinc, dry,

Second best " "

Best Zinc, ground and mixed, Second best." " " Best Oil of Vitriol,

"Acids,

"Mordants,

" display of articles maste by one concern, Silver Medal.

\section{DIVISION! Q.-ARCHITECTS.}

Open only to Architects of this State.

Superintendent: Henry J. Angell.

Best design for Dwelling House, cost completed not to be over $\$ 1500$,

Best design for Dwelling House, cost completed not to be over 2000 , Silver Medal. Diploma. Silver Medal. Diploma. 66

Best design for Dwelling House, cost completed not to be over $\$ 3000$,

Best design for Ice House, not to cost over $\$ 300$,

" " Barn, " " $\$ 1000$,

" $"$ Mouse and Rat Proof Crib,

'The designs that receive the Premiums to become the pro. perty of the Society.

\section{DIVISION R.-MISCELLANEOUS.}

Simperintendent: $D$ r. J.B. Chapin.

Best silk Comforter,

" patch work Comforter, woolen 66

"specimen of silk Embroidery,

" specimen of Crotchet Work, 

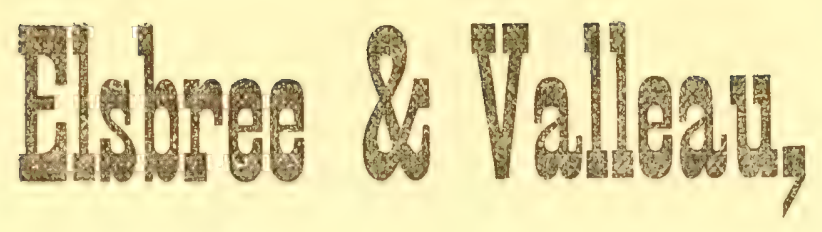

No. 63 Westminster Street,

$$
\begin{aligned}
& \text { PROVIDENCE, R. I. }
\end{aligned}
$$

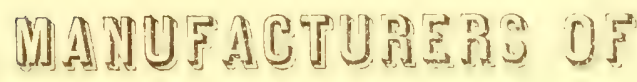

Hith ALSO DEALERS IN

\section{FURNISHING GOODS}

$$
E \odot E
$$

Gentlemen and Boys.

\section{Shirts Made to Order.}

Silk, Mlpacca and Gingham Umbrellas.

ALSO THE CELEBRATED

$$
\text { SAMPSON BRACES. }
$$




\section{8}

Best made Shirt, hand made,

" collection of useful and ornamental Needle

Work, made by one lady,

Second best,

" specimen of Wax Flowers,

" "Artificial Flowers,

" "Worsted Work,

" display of Millinery,

" " "Gents' Furnishing Goods, 15.00

" made Dress Hat,

" Rustic Work,

". specimen of Photographs,

" " " Chromo Lithographs, $\quad 3.00$

" Crayon Drawing,

" specimen of Penmanship,

\section{DIVISION S.- CANNED FRUIT'S, PRESERVES, PICKLES, \&C.}

Superintendent: Richmond P. Everett.

Best specimen of Canned Fruits,

. " " " Preserved Fruits,

" " and largest varieties of Jellies,

10.00

" " " of Pickles,

10.00

"Catsups,

\section{DIVISION T.-WOOL.}

Snperintendent: Richmond P. Everett.

\begin{tabular}{|c|c|c|c|c|c|}
\hline Best & splay of & washed & Cotswold flee & e Wool, & 10.00 \\
\hline & " 6 & “ & Nerino, & " & 10.00 \\
\hline "6 & ". & "، & Leicester, & .. & 10.00 \\
\hline .6 & “" & "“ & Sonthdown, & " & 10.00 \\
\hline$"$ & “ & Lamb': & Wool, & & 10.00 \\
\hline
\end{tabular}




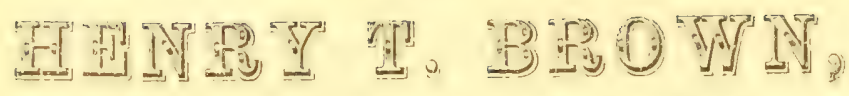 60 WETMINGTRR ST. Providence, R. I.}

IMURTER ANI) DEAHE IN

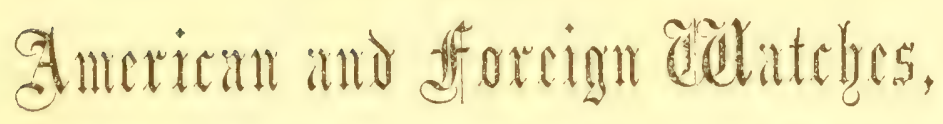 PARIS BRONZES \& MANTLE CLOCKS.}

GORHAM MANUFACTURING CO'S

\section{Silver and Electro-Plated Wares,}

\section{PLATED HOUSE-KEEPIMG GOOBS, CUTLERY, \&C.}

Triple-Plated Forks and Spoons.

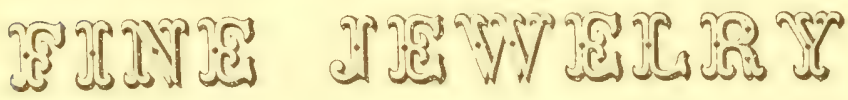

\section{A SPECTALTY.}

He would invite your attention to his cussortment of PLATED WATE. The quality the best, being TRIPLE and QUADRUPLE plate, on white metal, and he guarantees the prices as resonable as the same quality of plate is ever sold.

Rogerers Bros' Triple Plated Forks and Spoons, AT LOW PRICES. 


\section{DIVISION U.-JEWELRY, SILVER WARE \&C.}

Superintendent: Thomas A. Richardson.

Best display of Fine Gold Jewelry,

Silver Medal. Second best"

Best display of Silver Ware,

Second best "

"6

Best display of Shell Work,

" " Hair Work,

All goods to be of Rhode Islaud manufacture.

Diploma.

Silver Medal. Diploma.

Diploma.

Diploma.

DIVISION V.-PAINTINGS, STATUARY, \&C.

Superintendent: David A. Waldron.

The Committee have appropriated Richmond Hall, which is upon the same floor as Howard Hall, for the exhibition of j'aintings in Oil and Water Colors, and Statuary, of Rhode Island artists, and offer a Diploma to such artists as present articles of merit, 


\section{J. B. BARNABV DCO}

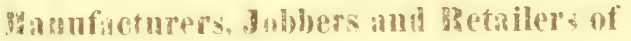

MENS, TOUTHS AND BOYS

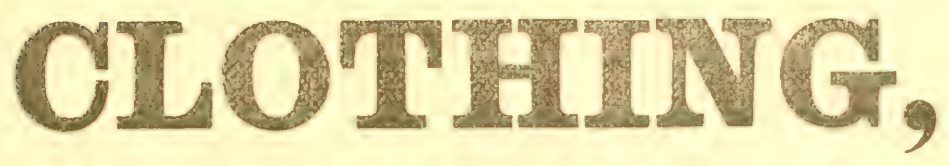

10, 12, 14 \& 16 South Main St,

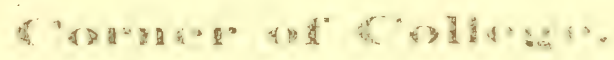

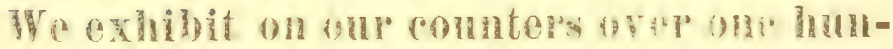
dred thousman dollages mopth of flothing for the retail trude, at less préce than ane louse in the City.

One Price ame ereig one treated alde.

\section{J. B. BARNABY \& CO.,}

Thi One Price Clothiers. 


\section{TH F:}

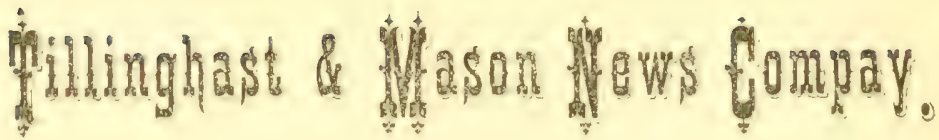

WHOLESALE AND RETAIL DEALERS IN

\section{Fancy Goods and Periodicals.} BOOKSELLERS AND STATIONERS.

The Trade supplied with everything in the

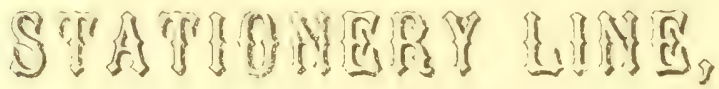

as low as they can buy in New York or Boston.

We are Headquarters for

$$
\begin{aligned}
& \text { OUT DOOR CROQUET, } \\
& \text { BASE BALLS, BATS, \&C. }
\end{aligned}
$$

Also Agents for all Newspapers and Periodicals published in EUROPE OR AMERICA.

\section{CEURCH BOOK STORE,}

AND

GE E E R L S L N I A I S II O O L

AND

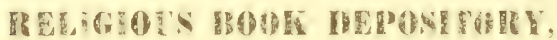

We make a specialty of

Sunday Sohnol, Ruligions, Juvenile,

Sunday School Singing Books,

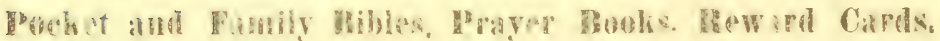

Metioes and Sunlay schond Bequisites

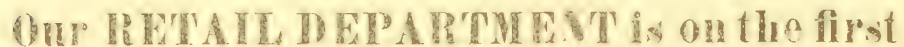
floor. and on Wholesale Department is in the Second and Ther Ntorios ar Stores Nos 113 o 115 Westminstor Sirect, Pror., R. I. 


\section{STANDARD BR00M C0.,}

MANUFACTURERS OF

\section{Prooms and Brushes,}

AND WHULESALE DEALERS IN

\section{Wooden Ware,}

\section{Willow Ware and Cords of every Description,}

121 Dyer St., Hoy Building, PROVIDENCE, R. I.

CHAS. S. JENCKES,

B. F. STANTOX.

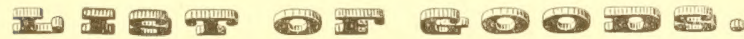

\section{PAIIS.}

Oak House Pails, "Horse "

2 and 3 Hoop assorted, Pine "

2 and 3 " Oak Grained, Half Pails,

2 and 3 "Blue \& Green, Can " 2 and 2 in, nest.

2 and 3 "Cedar B. B. Wood Hoop Pails,

2 and 3 " Pine B. B.

\section{TUBS.}

Blue 2, 3 and 8 in nest, Oak Grained 2,3 \& 8 in nest. White Pine 2 and 3 in nest, Cedar 2 and 3 in nest,

Large Tubs, in stacks.
BROOMS.

Pat. Carpet Brooms Hurl Brooms,

Stock " fancy, Mill

Toy

Hurl handle Whisk, Velvet Wood Hurl Coach All Corn

\section{BASKETS.}

Willow Clothes, Rattan

Willow Market, Lunch. Office, Oak Market,

"Bushel,

"s Bushel,

" Peck,
Oak Feed,

BRUSHES,

Dusting,

Serub,

Shoe,

Stove,

White Wash,

Floor,

Clothes,

Factory,

Horse.

\section{LINES,}

Cotton Clothes,

Jute

Jute Bed,

Hemp Bed,

Miscellaneous.

Churns,

Well Buckets,
Can Pails 2 \& 3 nest, Blueing,

Bail Boxes 2 in " Shoe Blacking Sugar " 5 in " Stove

Oak Nest Measures, Wood Bowls.

Clothes Pins, Chopping Trays,

Clothes Wringers, Chopping Knives,

Clothes Pounders, Saw Horses,

Zine Wash Boards, Woor Saws.

Wood is is Saw Frames,

Barrel Covers, Whip Lashes.

Axe Handles, Whip Stocks.

Rolling Pins, Paper Bags,

Pastry Boards, Flour

Towel Rolls, Flour Seives.

Knife Trays, Coal

Wood Spoons. Broom Handles

Cork Lined Fancets, " Corm.

Wood Dippers, " "Twine

Cocoanut Lippers, " "Wire

Lemon Squeezers, "T Tacks,

Bung Starts, Mouse Traps

Butter Ladles, Rat Traps,

Mop Sticks,

Coal Hods. 


\title{
RAILROAD HALLS
}

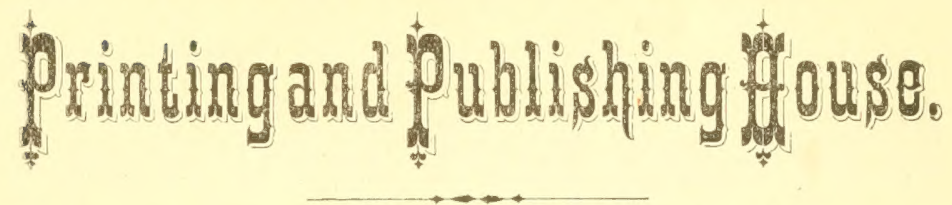

The subscriber respectfully anuonuces, with great pleasure, that he continues bis business at RAILROAD HALLS, and has added to his former extensive

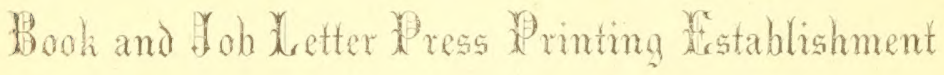

A Bees' Patent STEAM BOITER, 20-horse power, aud an 8-horse ENGINE, manthactured by Covel Iachine Co., of Fall River, and a

\section{NEW PATEYT UNIERSAL JOB PRESS,}

\section{$-\triangle N D \perp$ \\ Hoe Drum Cylinder Printing Machine}

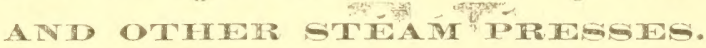

Together with a Large Quantity of PLAIN and ORNAMENTAL TYPE.

$$
\text { W } \mathrm{IV} O \mathrm{~W} \text { RUIJ }
$$

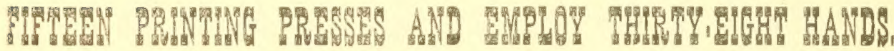

With these facilities we are enabled to tum out VAST QUANmities OF WORK

$$
\text { QUICK! NEAT!! OHEAP!!? }
$$

\section{The Providence Weekly Gazette.}

When we first convinced the idea of starting the present Weekly Gazette we based it tupon our experience in publishing the Weekly Times. The Times had paid us well, and the Gazette, thus far, bas netted us a better profit than ever the Times did.

Three Thousand Copies are printed weekly: two thousand of which are circulated in the wards or this city, which supplies one-quarter of the families in all the different wards, weekly, every week supplying new families in those wards, thereby taking four weeks to supply the entire city. The balance one thousand, goes into country villages th.rough the State: never two in succession in the same village. We think this is the whole secret of success. The Gazette has now been published five years, and has become a "fixed fact." We desire to give the readers of our paper a full reading page, but as yet have been unable to do so, but will as soon as our narrow limits rill admit.

Thankful for the very liberal patronage already received, we invile the citizens of the State generally. to call and see

\section{THE LARGEST PRINTING OFFICE}

\author{
EVER OPENED IN NEW ENGLAND.
}

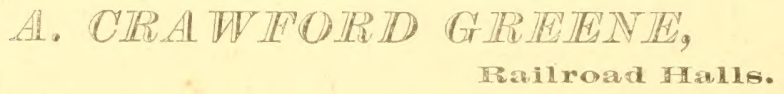




\section{PAPER WAREHOUSE,}

9 and 11 Exchange Sireet,

PROVIDENGE, R. I.

\begin{tabular}{|c|c|c|}
\hline $\mathbf{P}$ & s & Wrapping paper, \\
\hline$A$ & $\mathbf{T}$ & several sizes. \\
\hline $\mathbf{P}$ & $\mathbf{R}$ & - \\
\hline $\mathbf{E}$ & A & Flax, Hemp, Linen, \\
\hline $\mathbf{R}$ & W & Cotton, Jute and pa- \\
\hline B & $\mathbf{P}$ & per Twines, very low, \\
\hline A & A & - \\
\hline G & $\mathbf{P}$ & Tailer's Pattern Pa- \\
\hline $\mathbf{S}$ & $\mathbf{E}$ & per, Architect's Pa- \\
\hline $\begin{array}{l}\text { Manufactur- } \\
\text { g warranted, }\end{array}$ & $\mathbf{R}$ & $\begin{array}{l}\text { per, Manilla Wrap- } \\
\text { ping Paper, heavy }\end{array}$ \\
\hline & $\begin{array}{l}\text { Of all sizes at } \\
\text { low figures. }\end{array}$ & and light. \\
\hline
\end{tabular}

Of the best Manufacturers. Every bag warranted, and for sale lowet than the lowest.

low figures.

To those who contemplate building, we would say, do not build, unless you use our Sheathing Paper; also our Paper to between floors.

\section{Henry Staples de Con,}

Nos. 9 and I/ Exchange Street. 
$0002 \quad 6710431$

\section{CORY}

\section{BROTHERS,}

120 Westminster Si., Prov., R. I.

SOLE AGENTS FOR THE STATE, FOR

Ghickering \& Son's Grand fquare and ffpright

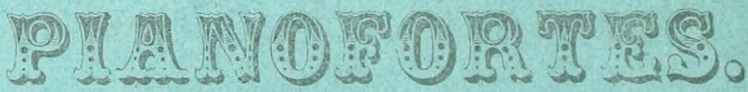

Willianl P. Fmersours and Hallett \& Cumston's Pianoortes.

AMERICAN ORGAN COMPANY, TAYLOR \&

FARLEY ORGAN COMPANY, AND THE SHONINGER COMPANY'S ORGANS AND MELODEONS.

First-class Seven Oclave Rosewood Case Pignoporters, with Stbol, sebt. WARRANTED FIVE YEARS. FOR SALE ONLY BY

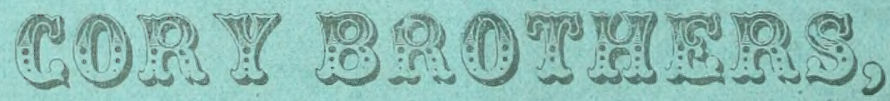
120 WESTMLNSTER ST.,

Pianos, Organs and Melodeons to Rent. 